\title{
Susceptibility of apple cultivars \\ to collar rot (Phytophthora \\ cactorum Leb. et Cohn. Schroet.)
}

\section{ZBIGNIEW BORECKI}

\begin{abstract}
Department of Plant Pathology, Warsaw Agricultural University SGGW-AR, ul. Nowoursynowska 166, 02-766, Poland
\end{abstract}

(Received: September 13, 1984)

\begin{abstract}
The susceptibility of 16 apple cultivars to collar rot caused by the fungus Phytophthora cactorum was tested. Three methods of evaluation were applied: a laboratory test, a greenhouse experiment and a field experiment. Two cultivars were very sensitive: 'Discovery' and 'Hibernal'. The next susceptibility group comprised the cultivars: 'Gloster', 'Florina', 'Liberty', 'Julyred', 'Paulared' and 'Jonnee'. Moderately susceptible were: 'Šampion', 'Nova Easygro', 'Jonagold' and 'Quinte'. Least susceptible were: 'Summerred', 'Nüred', 'Jonamac' and 'Spartan'. Not one of the tested cultivars was completely resistant to infection with Phytophthora cactorum. A high degree of correlation was noted between the results obtained in the greenhouse, in the field and in the laboratory test on annual shoots cut off at the dormant stage of the trees. Much less reliable results were obtained in the laboratory test on apple-tree shoots cut in September in the end stage of vegetation of the trees.
\end{abstract}

\section{INTRODUCTION}

The literature concerning susceptibility of apple cultivars to collar rot brings mainly information on older apple varieties. Numerous authors consider that 'Cox Organe' is a very susceptible variety (Alston, 1970; Braun and Nienhaus, 1959; Roosje, 1955; Krähmer and Schmidle, 1979; Kröber and Karnatz, 1979; Bielenin, 1975). As susceptible are also mentioned such cultivars as: 'Grimes Golden' (Anderson, 1956), 'Discovery' (Borecki and Czynczyk, 1985; Kröber and Karnatz, 1979), 'Laxton Superb' (Braun and Nienhaus, 1959; Kröber and Karnatz, 1979), 'Berlepsch' and 'James Grieve' (Braun and Nienhaus, 1959), 'Lord Lambourne' (Roosje, 1955) and 'Idared', 'McIntosh' and 'Orangeburg' (Krähmer and Schmidle, 1979). Alston (1970) also considered as susceptible such apple-trees as 'Laxton Superb' and 'James Grieve'. Many authors mention as susceptible the cultivars: 'Boskoop', 'Manzen', 'Melba' and 'Wealthy' (Braun and Nienhaus, 1959; Roosje, 1955; Krähmer and Schmidle, 1979; 
Kröber and Karnatz, 1979). Borecki et al. $(1978,1982)$ and Borecki and Czynczyk (1985) tested among others the susceptibility to Phytophthora cactorum of cultivars resistant to apple scab. Susceptible proved: 'Priscilla', 'Florina' and 'Macfree', and relatively resistant 'Freedom' (NY 58-553-1) and 'Prima'.

An important factor influencing the susceptibility of apple-trees to collar rot is the age of the trees. Most authors believe that the period of highest susceptibility falls to the age of 5-10 years, that is the years of highest fruit bearing (Bra un and Nienhaus, 1959; Grupta and Singh, 1979; Kröber and Karnatz, 1979; Söko and Lauvinen, 1981). Another important factor influencing the susceptibility of apple-trees to Phytophthora cactorum are the development phases of the trees in the course of vegetation. All authors dealing with this problem agree that appletrees are most susceptible in the period of bloom and further in the second half of summer (Braun and Nienhaus, 1959; Bielenin, 1975). Kröber and Karnatz (1979) observed an interesting fact, namely, that shoots growing vertically are more susceptible than the horizontal ones.

Several authors tried to establish the biochemical factors in the cortex parenchyma which influence the susceptibility of apple-trees to collar rot. Borecki et al. (1970) detected in the tree tissues compounds with a stimulating and inhibitory action on the growth of the fungus, and established the molecular weight and some chemical characteristics of these substances. Bielenin et al. (1973) claimed that floridzine is one of the inhibitors of growth of Phytophthora cactorum. Further investigations, however, did not confirm the relation between floridzine content in the tissues and susceptibility of the apple cultivars. The role of phenol and flavone compounds, floridzine and quercetine as factors influencing resistance was also investigated by Alt and Schmidle (1980).

Among external factors, soil humidity and temperature play an important role in the incidence of collar rot. Long lasting high humidity of the substrate favors appearance of the disease (Braun and Nienhaus, 1959; Al t, 1983). The influence of temperature is rather complex and depends largely on the kind of stock. Braun and Nienhaus (1959) ascertained that for development of Phytophthora cactorum on stock M9 the optimal temperature was $18-21^{\circ} \mathrm{C}$, and on stock M11 $24-26^{\circ} \mathrm{C}$. According to Alt (1983), optimal temperature for development of the fungus in vitro and on the stock is $27^{\circ} \mathrm{C}$. At temperatures below $5^{\circ} \mathrm{C}$ and above $30^{\circ} \mathrm{C}$ damage is only slight.

One of the difficulties encountered in investigations of the susceptibility of appletrees to collar rot are the wide differences in the pathogenicity of Phytophthora isolates. This problem was studied by Bielenin (1975), Aldwinckle et al. (1975) and Jeffers et al. (1982). Alston (1970) considers cultivation of resistant varieties as an important method of protection of apple-trees against collar root and he searched for genetic sources of resistance to this disease among 43 apple cultivars. As such source may serve the cultivar 'Norden Spy'.

A very important methodical problem connected with evaluation of susceptible stock and apple cultivars to Phytophthora cactorum is the way and conditions 
of artificial infection of the plants. Many authors call attention to the difficulties associated with artificial infection of apple-trees with the fungus Phytophthora cactorum (McIntosh, 1975). Most investigators applied the routine method of infecting the trees under field conditions in which evaluation of susceptibility lasts several or a dozen or so months. Borecki and Millikan (1969) developed a rapid test making possible evaluation of susceptibility, fungus pathogenicity and the role of various factors influencing pathogenicity. In this test the results can be obtained within 5-8 days. The latter method was modified and improved by Aldwinckle et al. (1975) and further by Jeffers et al. (1981, 1982), and used mainly for evaluation of the pathogenicity of fungi of the genera Phytophthora and Pythium. A similar method of artificial inoculation of cut off shoots was applied by Alston (1970). Kröber and Karnatz (1979) compared the results of laboratory tests and field experiments and confirmed the agreement of their results, they considered, however, like Alston the field results as more reliable.

\section{MATERIAL AND METHODS}

The aim of the research undertaken in the period 1982-1984 was establishment of the susceptibility of 16 apple cultivars to collar rot, including 11 new varieties in the conditions of Poland, three cultivars resistant to apple scab and two stand-

Table 1

Short description of tested apple cultivars*

\begin{tabular}{|c|c|c|c|c|}
\hline \multirow[b]{2}{*}{ Cultivar } & \multirow[b]{2}{*}{ Origin } & \multirow[b]{2}{*}{$\begin{array}{l}\text { Ripening } \\
\text { season }\end{array}$} & \multicolumn{2}{|c|}{ Susceptibility to } \\
\hline & & & apple scab & $\begin{array}{l}\text { apple powdery } \\
\text { mildew }\end{array}$ \\
\hline 'Discovery' & England & autumn & 2 & 2 \\
\hline 'Florina' & France & late winter & 1 & 2 \\
\hline 'Gloster' & FRG & late winter & 2 & 2 \\
\hline 'Hibernal' & Soviet Union & autumn & 2 & 1 \\
\hline 'Jonagold' & USA & winter & 2 & 2 \\
\hline 'Jonamac' & USA & autumn & 2 & 2 \\
\hline 'Jonnee' & USA & winter & 2 & 5 \\
\hline 'Julyred' & USA & early summer & 4 & 2 \\
\hline 'Liberty’ & USA & winter & 1 & 2 \\
\hline 'Nova Easygro' & Canada & winter & 1 & 5 \\
\hline ‘Nüred’' & USA & winter & 2 & 5 \\
\hline 'Paulared' & USA & late summer & 2 & 3 \\
\hline 'Quinte' & Canada & early summer & 5 & 2 \\
\hline 'Spartan’ & Canada & winter & 3 & 2 \\
\hline 'Summerred' & Canada & late summer & 2 & 2 \\
\hline ‘Šampion’ & Czechoslovakia & late autumn & 2 & 2 \\
\hline
\end{tabular}

* Susceptibility to apple scab and apple powdery mildew according to five degree scale: $1-$ resistant, $2-$ little susceptible, 3 - moderately susceptible, 4 - rather susceptible, 5 - highly susceptible. 
ard varieties ('Hibernal' and 'Spartan') (Table 1). Another aim was to compare various methods of evaluation of apple-tree resistance to the disease. The results of the laboratory test, the field experiment and the greenhouse experiment, where the conditions for development of the fungus were most favorable, were compared.

\section{Laboratory method}

This method has been described by Borecki and Millikan (1969). Annual shoots of apple-trees were cut into 6-8 cm segments and the bark was cut off on one side, exposing the phloem and cambium. Explants of a 6-day culture of the fungus Phytophthora cactorum were placed on the thus prepared segments. After incubation for five days in a moist chamber at $26^{\circ} \mathrm{C}$, the length of the necrosis was measured on the parts deprived of bark. Each of the 16 cultivars was one combination and had ten replications. In each replication ten shoots were infected. The laboratory methods was applied in two versions: young shoots cut in the second half of summer were infected at the beginning of September, and so were shoots in the stage of dormancy cut in December.

\section{Field method}

The experiments were performed in the years $1982-1984$ on two-year-old appletrees. The trees were planted in the autumn of 1982 and infected at the beginning of May 1983, in the period of highest susceptiblity of apple-trees to collar rot. On the tree stems a strip of bark was cut off and the wound was covered with an explant of the fungus culture of $12 \times 4 \mathrm{~mm}$ size. The inoculated wounds were wrapped with a band of foil which was removed after four weeks. Twelve months later the wounds formed at the site of infection were measured. Each cultivar was represented by 15 trees, from which ten were chosen for precise measurements with elimination of the poorly growing ones.

\section{Greenhouse method}

The experiment was performed in the year 1983. Ten trees of each variety were planted in March on deep beds filled with heavy clayey soil mixed with bark. In the initial stage of shoot growth the young trees were infected as in the field experiment. The whole time a high temperature was maintained in the greenhouse within the limits of $22-32^{\circ} \mathrm{C}$ and a high air moisture $80-95 \mathrm{rh}$. The trees grew much faster in the greenhouse than in the field. The wounds developed throughout the 1983 season and they were measured after a lapse of 10 months from inoculation.

The length of the wounds caused by Phytophthora cactorum was the index of susceptibility to the disease. The results of wound measurement were statistically elaborated and susceptibility was compared within each experiment. In statistical 
Table 2

Susceptibility of apple cultivars to collar rot (Phytophthora cactorum)

\begin{tabular}{|c|c|c|c|c|c|}
\hline \multirow{3}{*}{ Cultivar } & \multicolumn{4}{|c|}{ Mean length of lesion $(\mathrm{mm})$ : } & \multirow{3}{*}{ Susceptibility group } \\
\hline & \multirow[t]{2}{*}{ in greenhouse } & \multirow[t]{2}{*}{ under field conditions } & \multicolumn{2}{|c|}{ under laboratory conditions: } & \\
\hline & & & in Sept. & in Dec. & \\
\hline 'Hibernal' & $78.9 \mathrm{e}$ & $62.8 \mathrm{e}$ & $44.8 \mathrm{f}$ & $45.1 \mathrm{e}$ & highly \\
\hline 'Discovery' & $70.3 \mathrm{e}$ & $60.1 \mathrm{e}$ & $30.3 \mathrm{~d}$ & 50.3 ef & susceptible \\
\hline 'Gloster' & $59.9 \mathrm{~d}$ & $60.4 \mathrm{e}$ & $21.5 \mathrm{c}$ & $37.7 \mathrm{~d}$ & rather \\
\hline 'Florina' & $59.3 \mathrm{~d}$ & $52.4 \mathrm{~d}$ & $31.9 \mathrm{de}$ & $51.4 \mathrm{f}$ & susceptible \\
\hline 'Liberty' & $54.6 \mathrm{~d}$ & $49.9 \mathrm{~cd}$ & $18.4 \mathrm{bc}$ & $40.8 \mathrm{de}$ & \\
\hline 'Julyred' & $53.9 \mathrm{~d}$ & $44.3 c$ & $15.4 \mathrm{~b}$ & 48.1 ef & \\
\hline 'Paulared' & $52.4 \mathrm{~d}$ & $47.1 \mathrm{~cd}$ & $37.0 \mathrm{e}$ & $37.7 \mathrm{~d}$ & , \\
\hline 'Jonnee' & $50.6 \mathrm{~cd}$ & $40.5 \mathrm{bc}$ & $16.9 \mathrm{~b}$ & $36.1 \mathrm{~d}$ & \\
\hline 'Šampion' & $45.9 \mathrm{~cd}$ & $41.1 \mathrm{bc}$ & $16.0 \mathrm{~b}$ & $39.4 \mathrm{~d}$ & moderately \\
\hline 'Nova Easygro' & $44.8 \mathrm{~cd}$ & $39.4 \mathrm{bc}$ & $48.9 \mathrm{f}$ & $25.3 \mathrm{c}$ & susceptible \\
\hline 'Jonagold' & $43.6 \mathrm{c}$ & $31.3 \mathrm{ab}$ & $22.5 \mathrm{c}$ & $27.5 \mathrm{c}$ & \\
\hline 'Quinte' & $40.8 \mathrm{bc}$ & $35.6 \mathrm{~b}$ & $16.5 \mathrm{~b}$ & $19.1 \mathrm{~b}$ & \\
\hline 'Summerred' & $37.8 \mathrm{bc}$ & $30.3 \mathrm{a}$ & $17.1 \mathrm{~b}$ & $16.0 \mathrm{a}$ & little \\
\hline 'Nüred' & $36.7 \mathrm{~b}$ & $37.9 \mathrm{~b}$ & $11.8 \mathrm{a}$ & $18.1 \mathrm{~b}$ & susceptible \\
\hline 'Jonamac' & $33.1 \mathrm{ab}$ & $31.4 \mathrm{a}$ & $17.5 \mathrm{~b}$ & $15.8 \mathrm{a}$ & \\
\hline 'Spartan' & $30.7 \mathrm{a}$ & $31.4 \mathrm{ab}$ & $21.8 \mathrm{c}$ & $16.4 \mathrm{ab}$ & \\
\hline
\end{tabular}

Means within a vertical column followed by the same letters are not significantly different at $5 \%$ level of probability. 
elaboration analysis of variance and Duncan's test were used. Moreover, the agreement of results obtained in the laboratory, glasshouse and field experiments was established by the method of linear correlation.

\section{RESULTS}

Wide differences were found in the degree of susceptibility of the tested apple cultivars to collar rot (Table 2). To rather sensitive varieties belonged: 'Gloster', 'Julyred', 'Paulared' and 'Jonnee' and two varieties resistant to scab: 'Florina' and 'Liberty'. Moderately resistant were: 'Šampion', 'Jonagold' and 'Quinte' and the variety resistant to scab 'Nova Easygro'. Least resistant proved: 'Summerred', 'Nüred', 'Jonamac' and 'Spartan'. This classification is based on greenhouse experiments, confirmed mostly by results of field experiments and laboratory tests performed on annual apple-tree shoots cut at the stage of dormancy.

The agreement of results obtained in greenhouse and field experiments and in the December laboratory test confirm the high coefficients of linear correlation, $\mathrm{r}$ varying from 0.820 to 0.939 (Table 3 ). The results obtained with shoots cut in September, however, differ widely from the foregoing ones, are but weakly correlated with those of the greenhouse experiment $(r=0.511)$ and practically show no correlation with those of the field experiment $(r=0.448)$ and December test $(\mathrm{r}=0.314)$.

\section{Table 3}

Values of coefficient of linear correlation $r$ for dependence between length of lesions developed in greenhouse, under field conditions and under laboratory conditions

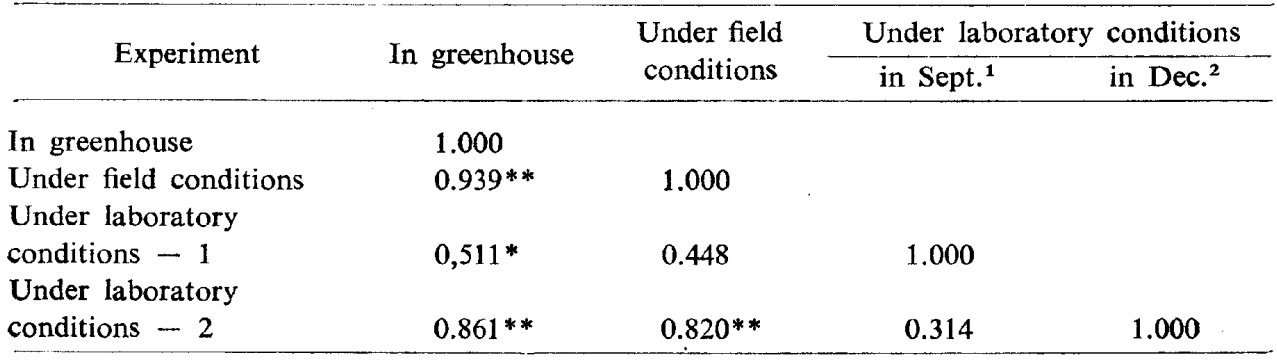

* Significance of coefficient of linear correlation at $5 \%$ level.

** Significance of coefficient of linear correlation at $1 \%$ level. 1 - end of growing season of apple tree. 2 - dormant stage of apple tree.

\section{DISCUSSION AND CONCLUSIONS}

The susceptibility evaluation of 16 apple cultivars to collar rot indicated that all the new apple varieties were susceptible to infection with Phytophthora cactorum and not one could be qualified as completely resistant or very slightly susceptible. The high susceptibility of the cultivars 'Hibernal' and 'Discovery' was confirmed 
(Borecki and Czynczyk, 1985). The high susceptibility of 'Discovery' has also been reported by Kröber and Karnatz (1979). The low resistance of the remaining cultivars has so far not been mentioned in the literature. Among the varieties classified to highly or rather susceptible there are both summer ('Julyred', 'Paulared') autumn ('Hibernal', 'Discovery') and winter varieties ('Jonnee', 'Liberty', 'Gloster', 'Florina'). Similar differences in the dates of ripening can be seen in the group of apple-trees little susceptible to collar rot. To this group belong: the summer appletree ('Summerred'), the autumn ('Jonamac') and two winter cultivars ('Nüred' and 'Spartan'). Neither was there any relation noted between susceptibility to collar rot and that to apple scab and mildew (Tables 1 and 2).

Accurate evaluation of the sensitivity of apple varieties to Phytophthora cactorum requires investigations of many years and multiple repeating of experiments under various conditions. This is indicated by the up-to-date discrepancies in the views of authors on the susceptibility of stock and of the cultivars 'James Grieve' and 'Laxtons Superb' (Alston, 1970; Bra un and Nien haus, 1959; Kröber and Karnatz, 1979). The authors views are concordant only in the case of very susceptible apple-trees such as 'Grimes Golden' and 'Cox Orange'.

On the basis of the results of experiments and observation of the development of bark necroses after artificial inoculation, as most reliable may be considered the results of greenhouse experiments where the disease develops fastest without disturbances caused by air temperature variations and moisture.

Each of the methods applied has some merits. The laboratory test is rapid and makes preliminary evaluation of sensitivity possible. The greenhouse conditions ensure a rapid growth of the fungus in the apple bark, and the field experiments confirm the results under conditions prevailing in orchards. The wide variability of susceptibility of apple-trees to collar rot indicates the usefulness of laboratory tests on shoots cut after the end of vegetation of the trees. This test can be performed with the use of various techniques described in the literature (Borecki and Millikan, 1969; Aldwinckle et al., 1975; Alston, 1970; Jeffers et al., 1981, 1982). The high correlation coefficients in the results of laboratory tests performed on shoots cut in December and the experiments run in the greenhouse and in the field are evidence of the usefulness of application of complex methods making possible reduction of the period of investigation and revealing many factors affecting the development of Phytophthora cactorum on infected apple-trees.

\section{REFERENCES}

Anderson H. W., 1956. Diseases of fruit crops. McGraw-Hill Book Comp., New York, Toronto, London.

Aldwinckle H. S., Polach F. J., Molin W. T., Person R. C., 1975. Pathogenicity of Phytophthora cactorum from New York apple and other sources. Phytopath. 65: 989-994.

Alston F. H., 1970. Resistance to collar rot, Phytophthora cactorum (Leb. et Cohn.) Schroet. Rep. East Mall. Res. Sta. for 1969: 143-145. 
Alt D., 1983. Investigations on the influence of temperature on infection by Phytophthora cactorum (Leb. et Cohn.) Schroet. in apple variety Cox Organe as a function of the rootstocks M9 and M11. Angewandte Botanik 57: 69-76.

Alt D., Schmidle A., 1980. Investigations on potential resistance factors of apple to Phytophthora cactorum. Angewandte Botanik 54: 139-156.

Bielenin A., 1975. Grzyb Phytophthora cactorum (Leb. et Cohn.) Schroet. jako patogen jabłoni w warunkach Polski. Praca doktorska SGGW - AR.

Bielenin A., Cimanowski J., Nowacki J., 1973. The effect of some endogenic substances contained in the cortical parenchyma of apple trees on growth in vitro the fungus Phytophthora cactorum. Acta Agrobot. 26: 265-272.

Borecki Z., Czynczyk A., 1985. Susceptibility of apple cultivars to bark canker diseases. Acta Agrobot. 38: 49-59.

Borecki Z., Millikan D. F., 1969. A rapid method for determining the pathogenicity and factors associated with pathogenicity of Phytophthora cactorum. Phytopath. 59: 247-248.

Borecki Z., Ross J. A., Millikan D. F., 1970. Endogenous factors in apple bark which stimulate and inhibit the growth of Phytophthora cactorum. Phytopath. 60: 173-174.

Borecki Z., Czynczyk A., Millikan D. F., 1978. Susceptibility of several cultivars of apple to bark canker fungi. Plant Dis. Reptr. 62: 817-819.

Borecki Z., Czynczyk A., Puchała Z., Millikan D. F., 1982. Resistance in apple to four bark canker fungi. Plant Dis. 66: 1027-1029.

Braun H., Nienhaus F., 1959. Fortgeführte Untersuchungen über die Kragenfaüle des Apfels (Phytophthora cactorum). Phyt. Zeitsch. 37: 167-288.

Grupta V. K., Singh K., 1979. Factors affecting the development of collar rot (Phytophthora cactorum) of apple. Gartenbauwissenschaft 44: 29-32.

Jeffers S. N., Aldwinckle H. S., Burr T. J., Arneson P. A., 1981. Excised twig assay for the study of apple tree crown rot pathogens in vitro. Plant Dis. 65: 823-825.

Jeffers S. N., Aldwinckle H. S., Burr T. J., Arneson P. A., 1982. Phytophthora and Pythium species associated with crown rot in New York apple orchards. Phytopath. 72: 533-538.

Krähmer H., Schmidle S., 1979. On the susceptibility of some recent apple varieties to Nectria galligena Bres. and Phytophthora cactorum (Leb. et Cohn.) Schroet. Nachtrichbl. des Deutsch. Pflanzenschutzdienstes $31: 89-92$.

Kröber H., Karnatz A., 1979. Susceptibility of apple cultivars to Phytophthora cactorum and dependence on different factors. Zeitschr. für Pflanzkrank. und Pflanzschutz. 86: 1-11.

McIntosh D. L., 1975. Proceedings of the 1974 APWD workshop on crown rot of apple trees. Can. Plant Dis. Survey 55: 109-116.

Roosje G. S., 1955. Various aspects of Phytophthora cactorum collar-rot of apple trees in the Netherlands. Tijdschr. over Plantenziekt. 61: 122-129.

Söko J., Lauvinen E., 1981. Incidence of collar rot in apple trees in Finland 1975-1979. Ann. Agr. Fenniae 20: 261-267.

Wraźliwość odmian jabłoni na zgniliznę pierścieniową podstawy pnia (Phytophthora cactorum Leb. et Cohn. Schroet.)

\section{Streszczenie}

Zbadano wrażliwość szesnastu odmian jabłoni na zgniliznę pierścieniową podstawy pnia powodowaną przez grzyb Phytophthora cactorum. Do oceny wrażliwości zastosowano trzy metody: test laboratoryjny, doświadczenie w szklarni i doświadczenie polowe. Dwie odmiany 'Discovery' 
i 'Hibernal' były bardzo wrażliwe. W drugiej grupie wrażliwości znalazły się odmiany: 'Gloster', 'Florina', 'Liberty', 'Julyred', 'Paulared' i 'Jonnee'. Średnio wrażliwe były: ‘Śampion', 'Nova Easygro', 'Jonagold' i 'Quinte'. Najmniej wrażliwe okazały się: 'Summerred', 'Nüred', 'Jonamac' i 'Spartan'. Żadna z badanych odmian jabłoni nie wykazała całkowitej odporności na porażenie przez grzyb Phytophthora cactorum. Stwierdzono wysoki stopień korelacji pomiędzy wynikami uzyskanymi w szklarni, w polu i w teście laboratoryjnym na jednorocznych pędach wyciętych w stadium spoczynku drzew. Znacznie mniej miarodajne wyniki uzyskano $\mathrm{w}$ teście laboratoryjnym na pędach jabłoni wyciętych we wrześniu, w końcowym stadium wegetacji jabłoni. 